\title{
Leishmaniose visceral: história jornalística de uma epidemia em Belo Horizonte, Brasil
}

\author{
Paula Dias Bevilacqua ${ }^{1}$ \\ Helena Heloísa Paixão \\ Maria Ceres Pimenta Spinola Castro \\ Celina Maria Modena ${ }^{4}$
}

BEVILACQUA, P.D. et al. Visceral leishmaniasis: the journalistic history an epidemic in the city of Belo Horizonte, Brazil, Interface _ Comunicação, Saúde, Educação, v.4 , n. 7, p.83-102, 2000.

The objective of this paper is to recover the journalistic history of the visceral leishmaniasis epidemic that has been affecting the city of Belo Horizonte, Brazil, since 1993. It was pieced together from its chronological history, as well as from the narratives and discourses on the epidemic in 101 articles published by the mass media between 1993 and 1996. As regards methodology, the analysis relied on a proposal of Foucault's described in his 1972 work, " $A$ Arqueologia do Saber" (The Archeology of Knowledge), and it highlights the existence of three major lines of discourse, which characterize thematic groups, in the subject matters studied, i.e., discourse produced by Science, by the State and by Society. Each one of them makes its own contribution as to how the illness is depicted in the journalistic universe, and puts forth its own views on these arenas. Thus, by studying journalistic texts, one can decipher another epidemic process that developed concurrently with the one affecting human beings and dogs, expressed in the narrative constructions on visceral leishmaniasis in newspaper articles.

KEY WORDS: leischmaniasis visceral; mass media; disease outbreaks.

Este trabalho busca recuperar a história jornalística da epidemia de leishmaniose visceral que acomete o município de Belo Horizonte, Brasil, desde 1993. Este resgate se fez através da sua história cronológica e das construções narrativas e discursivas sobre a epidemia em 101 matérias publicadas na grande imprensa, durante o período de 1993 a 1996. Utilizando-se como orientação metodológica a proposta de Foucault (1972), em seu trabalho "A Arqueologia do Saber", a análise aponta para a configuração de três grandes discursos, caracterizando grupos temáticos, nas matérias estudadas: o da Ciência, o do Estado e o da Sociedade. Cada um dos grupos contribui para a construção da doença no espaço jornalístico e veicula opiniões próprias de cada um destes universos. Dessa forma, a leitura dos textos jornalísticos permite o desnudamento de outro processo epidêmico, que se desenvolve paralelamente àquele que acomete as populações humana e canina, expresso nas construções narrativas sobre a leishmaniose visceral nos textos de jornal.

PALAVRAS-CHAVE: leishmaniose visceral; meios de comunicação de massa; surtos de doenças.

\footnotetext{
${ }^{1}$ Professora do Departamento de Veterinária, Universidade Federal de Viçosa. <paula@mail.ufv.br>

2 Professora da Faculdade de Odontologia, Universidade Federal de Minas Gerais.

3 Professora da Faculdade de Filosofia e Ciências Humanas, Universidade Federal de Minas Gerais.

${ }^{4}$ Professora da Escola de Veterinária, Universidade Federal de Minas Gerais.
} 
Comunicação Social e a produção de conhecimento e comportamentos

A Comunicação Social, na atualidade, tem sido explorada por várias áreas do conhecimento, que procuram aproximar campos de práticas e de investimentos teórico-metodológicos bastante complexos. Este processo foi possibilitado a partir da conscientização a respeito da grande importância que a comunicação adquiriu na sociedade contemporânea, como por exemplo, no que diz respeito aos reais poderes e possibilidades dos aparatos de comunicação e informação, considerados como um dos grandes fenômenos do século XX.

Além disso, a implantação de uma rede mundial de telecomunicações possibilita a uma grande parcela da população receber diariamente notícias de outras sociedades e incorporar à cultura a noção, ainda que pobre e caricata, do global. As transformações e possibilidades derivadas deste processo estão ocorrendo muito próximas a nós, dentro das residências, levando-nos a perceber, mesmo que discretamente, a magnitude e onipotência que os meios de comunicação representam em nosso cotidiano.

Entretanto, mais do que o papel de difusão de informações diminuindo as fronteiras físicas e espaciais entre o emissor e o receptor da mensagem, os meios de comunicação têm o papel fundamental de interferir no comportamento e na constituição de um imaginário social que permeia o conjunto da sociedade.

É neste sentido que Oliveira (1995) nos fala que não podemos considerar o discurso como uma mera transmissão de informações, mas, antes, como efeitos de sentidos, pois "os discursos são socialmente situados e são sempre o resultado de um conjunto simbólico de forças que procuram nomear, hierarquizar, interpelar ou acionar os sujeitos sociais." (p.26)

Obviamente que vários outros campos sociais, como a escola, a saúde, o saber médico e o político, afiguram-se como importantes campos a influenciar o comportamento dos indivíduos. Entretanto, nas sociedades modernas, fortemente influenciadas pela proliferação dos meios de comunicação de massa e por uma relativa estrutura de consumo de bens simbólicos e materiais, existe uma fragmentação do poder que permeia os campos sociais, os quais lutam para interferir na esfera pública. Contudo, esses campos não interpelam ou proferem mensagens neste espaço por si mesmos, e, sim, nediante as mídias que, a cada dia, se tornam o seu principal ator (Oliveira, 1995).

Esta última questão também é referenciada por Rondelli (1995) quando sugere, citando particularmente a televisão, que os meios de comunicação aparecem como o lugar da ampliação do intercâmbio dos discursos construídos em vários campos do saber. Esta autora identifica em seu trabalho alguns discursos que trazem como tema a saúde, a doença e o corpo, disponibilizados para a sociedade diariamente. Assim, tem-se:

a) o da medicina, como discurso lógico, racional e científico, cujos lugares de realização são as pesquisas divulgadas em congressos e encontros;

b) o dos médicos e o de outros profissionais da saúde, ou seja, o de uma "comunidade da saúde", elaborado a partir da rotina de trabalho cotidiana, que, embora informado pelo primeiro nível, não deixa de especificá-lo, a 
partir das circunstâncias e dos limites conjunturais da prática profissional diária;

c) o das interpretações, leituras e dos usos e não-usos que os pacientes fazem dos diagnósticos e das prescrições médicas, costuradas com noções herdadas do senso comum;

d) o do público leigo que se depara, sobretudo, com o cruzamento e a interposição de várias lógicas de linguagem e que, a partir deste mixed formado por discursos de origens múltiplas, elabora suas próprias conclusões - cientificamente corretas ou não - , reconhece-as como verossímeis e dignas de crédito, validando-as como guias de comportamento, que podem ser até incoerentes, por operarem com lógicas distintas ou mesmo que se defrontam;

e) o dos meios de comunicação, os quais compreendem vários tipos de publicações, especializadas ou não, como: publicações científicas. livros e revistas, a grande imprensa e outros.

Neste sentido, os vários eventos mórbidos que acometem as diversas populações encontram nos meios de comunicação um outro espaço de circulação e disseminação, legitimados por meio de um discurso médico-científico competente. Além disso, a opiniãc expressa pelos meios de comunicação reproduz as representações

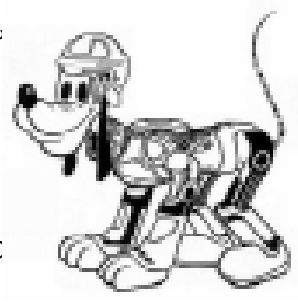
sobre o adoecer e morrer características dos grupos sociais, as quais, necessariamente, não revelam relação ou compromisso com as demandas reais por serviços ou ações de saúde da comunidade como um todo.

\section{Tratamento das matérias jornalísticas}

Os processos epidêmicos podem ser descritos, analisados e entendidos de uma forma eminentemente quantitativa, utilizando-se, para este fim, gráficos, tabelas, coeficientes, indicadores e outros instrumentos de análise, caracterizando o evento a partir de um olhar probabilístico e numérico.

Entretanto, os números isoladamente podem ser limitados ou limitantes ao pesquisador que busca inferir explicações mais totalizantes dos eventos em saúde, ou seja, que procura ultrapassar o entendimento reducionista e fragmentador do objeto característico da análise de risco tão em voga na Epidemiologia atual.

Por outro lado, a interface que esta ciência se permitiu realizar com a área das Ciências Humanas possibilitou o conhecimento e, sem dúvida mais relevante, a utilização de vários instrumentais de análise, originalmente das Ciências Humanas e perfeitamente adaptáveis para a Ciência Epidemiológica, para uma compreensão menos parcelada dos fenômenos da saúde.

o presente trabalho apresenta uma abordagem diferente do tratamento quantitativo dos dados produzidos durante um processo epidêmico, o que, obviamente, não exclui ou inviabiliza a análise numérica, mas constituindo uma análise sob outra ótica, vem, minimamente, complementar o conhecimento subjacente.

O evento escolhido como foco de análise foram as epidemias humana e canina de leishmaniose visceral que acometem o município de Belo Horizonte/MG, desde 1993. Esta enfermidade caracteriza-se, 
epidemiologicamente, por apresentar o cão como o principal reservatório urbano, sendo transmitida, em nosso meio, entre a população canina e desta para o homem pelo inseto vetor Lutzomyia longipalpis (Genaro, 1997).

Por outro lado, a epidemia de leishmaniose visceral (calazar) constituiu-se como acontecimento jornalístico, passando a fazer parte da agenda da grande imprensa circulante no município de Belo Horizonte.

Foram selecionadas todas as matérias jornalísticas publicadas pela grande imprensa no período de 1993 a 1996. Estas matérias receberam, inicialmente, um tratamento descritivo, caracterizando o componente morfológico da análise de discurso ${ }^{5}$. Neste segundo momento, a leitura das matérias teve como objetivo a análise de seus conteúdos enunciativos para se reconstruir a história da epidemia como fato jornalístico.

Apesar de a análise de discurso ser concebida com uma base sociológica e uma base linguística, optou-se por privilegiar a análise sociológica, tendo como orientação metodológica a proposta de Foucault (1972), em seu trabalho "A Arqueologia do Saber".

A análise que se segue foi fracionada, segundo o ano de publicação da matéria, para que fosse possivel uma comparação simultânea da evolução das epidemias humana e canina, verificadas a partir de informações referentes a casos e óbitos humanos e às medidas de controle do reservatório e do vetor fornecidas pelo Núcleo de Epidemiologia (NEP) e pelo Serviço de Controle de Zoonoses (SCZ) da Secretaria Municipal de Saúde da Prefeitura de Belo Horizonte (SMSA/PBH).

\section{"Leishmaniose visceral sai do campo e começa a chegar a BH"6}

O ano de início de estudo deste trabalho, 1993, apresentou, ao todo, sete notícias publicadas na grande imprensa referentes ao tema leishmaniose visceral. Entretanto, apenas uma notícia, publicada no mês de outubro, cita, especificamente, a epidemia de leishmaniose visceral que já acometia Belo Horizonte desde o ano anterior. Nas outras matérias, a epidemia em Belo Horizonte aparece de forma secundária, articulada a outros temas, como: desenvolvimento de vacina contra o calazar, movimento grevista do serviço público ou urbanização de doenças rurais.

Quatro matérias sugerem uma possível urbanização do calazar e de outras enfermidades, como a leishmaniose tegumentar e a raiva, características do ambiente rural. Apesar de fazerem referência a um potencial despreparo dos serviços de saúde pública para lidarem com os problemas emergentes, procuram justificar a urbanização como resultante de desequilíbrios ambientais oriundos de desmatamentos e outras atividades humanas. Além disso, citam o processo de ocupação do espaço urbano de forma não organizada, gerando áreas sem infra-estrutura básica de saneamento e outros serviços.

O desequilíbrio ambiental pelo desmatamento, monoculturas, migração e urbanização desenfreada, sem infra-estrutura de serviços básicos têm causado uma verdadeira 'revolução dos bichos'. Antes confinados na mata, os insetos e répteis agora
${ }^{5}$ Detalhes desta análise preliminar estão descritos em Bevilacqua et al. (1999a).
${ }^{6}$ Leishmaniose... (1993) 
invadem as cidades e formam um novo perfil epidemiológico de doenças, que não causavam tanto temor por serem consideradas silvestres, como é o caso da Leishmaniose Visceral e Tegumentare da raiva transmitida por morcegos.

[...] O aparecimento ou a volta de doenças pode ser atribuído, em alguns casos, à falta de ações da saúde pública, mas em outros a culpa é do próprio modelo de desenvolvimento econômico. A advertência é do epidemiologista da Escola Nacional de Saúde Pública (ENSP), Paulo Sabroza: 'Nosso modelo de desenvolvimento levou a formas de organização do espaço que fizeram surgir novos nichos ecológicos para velhos parasitas'. A expulsão do homem do campo e como conseqüência a desenfreada urbanização dos centros urbanos, sem infra-estrutura de saneamento, são fatores citados pela epidemiologista da Secretaria Estadual de Saúde, Isabel Teixeira, como os mais agravantes do modelo brasileiro de desenvolvimento. Enumera, ainda, a miséria e a falta de investimento na educação, $e$ atualmente o total sucateamento da saúde pública, que: 'não tem preparo para trabalhar com esse novo quadro epidemiológico'.

As doenças antigas que já se pensavam erradicadas ressurgem novamente nesse ambiente favorável à sua proliferação."

(Santos..., 1993) (grifos da autora)

Os indivíduos emissores desses relatos compreendem, em sua maioria, profissionais da Secretaria Estadual de Saúde do Estado de Minas Gerais (SES/MG) e professores da Escola Nacional de Saúde Pública da Fundação Oswaldo Cruz (ENSP/FIOCRUZ). Essas citações denunciam um quadro bastante atual de crescente descaso das instâncias governamentais com serviços básicos de cunho social como saúde, educação e saneamento. Além disso, imputam grande responsabilidade ao processo de urbanização desenfreado e sem planejamento que vem se desenvolvendo nos grandes centros.

Na realidade, as enfermidades relacionadas nas notícias de jornal, como a raiva, a leishmaniose tegumentar e o próprio calazar, nunca deixaram de fazer parte do cotidiano, por exemplo, das populações rurais, contrariando um dos relatos que faz referência a "...doenças antigas que já se pensavam erradicadas ressurgem novamente...".

Não se trata, então, de aceitarmos a idéia de que este quadro de saúde é um retrocesso a uma conjuntura epidêmica igual à que marcou a expansão do capitalismo no século passado. Como nos relatam Sabroza et al. (1995), esta idéia não assume as profundas transformações ocorridas nas sociedades, $o$ que nos leva a afirmar que agora essas mesmas doenças são expressão de novos processos e problemas de saúde, decorrentes da modernidade perversa estabelecida pelo modelo de desenvolvimento capitalista dependente, agora em sua fase pós-industrial.

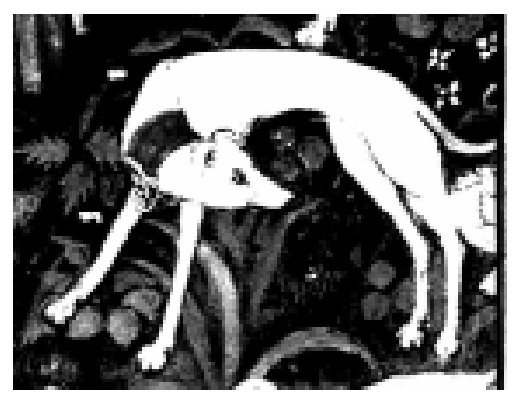

agosto, 2000 
Neste cenário, devemos salientar a importância dos fluxos migratórios em modificar os perfis epidemiológicos de ocorrências das enfermidades, relatada por Carvalheiro (1986, p.32), referindo-se à doença meningocócica na cidade de São Paulo, da seguinte forma:

O intenso processo de absorção de migrantes oriundos do interior
do Estado e dos demais Estados do país é extremamente
importante na configuração dos perfis epidemiológicos, uma vez
que os migrantes representam grupo particular de risco, quer seja
por suas condições geralmente precárias de inserção social, quer
seja pela ausência de imunidade para as doenças existentes nas
grandes áreas urbanas, dentre as quais a doença meningocócica.

Interessante, que o migrante tanto pode ser considerado como grupo de maior risco, pelas razões expostas acima, como ser responsabilizado pela introdução de enfermidades características de suas áreas de origem. Fato este que pode ser exemplificado pela leishmaniose visceral, uma vez que sua disseminação pode ser atribuída aos cães que normalmente acompanham as famílias de migrantes ${ }^{7}$.

A urbanização da leishmaniose visceral é, então, imputada como resultante da presença de cães infectados na cidade, os quais foram introduzidos juntamente com indivíduos que migraram para os centros urbanos oriundos de regiões reconhecidamente endêmicas como o Nordeste do Estado.

"Os cães chegaram com seus donos do Nordeste de Minas, avalia Mayrink" (Biotério..., 1993).

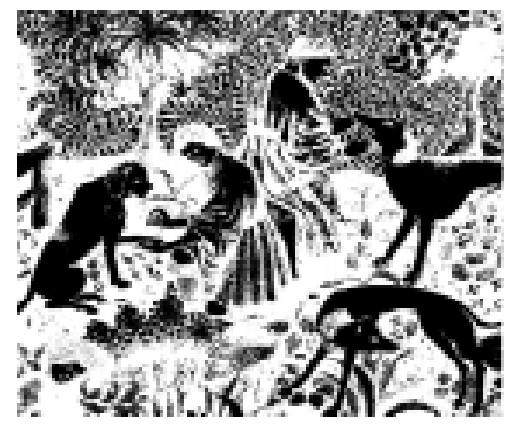

Deparamo-nos então, neste período, com o calazar às portas de Belo Horizonte. Entretanto, a urbanização da leishmaniose visceral, em várias cidades dos Estados do Nordeste do Brasil, já havia sido prevista nos idos da década de cincoenta pelo trabalho realizado por Deane (1956) no Ceará. Os resultados da pesquisa de Deane foram a primeira descrição de leishmaniose canina urbana no Brasil.

Este autor sugere que este processo possa existir em outras cidades nordestinas em função das correntes migratórias que se estabelecem das áreas afetadas pela seca para os centros urbanos sugerindo, conscientemente ou não, a força da determinação social no processo saúde-doença.

Apesar desta antiga advertência, o descompromisso do Estado com as condições de vida da população é cada vez mais acentuado, deixando evidente que a urbanização da leishmaniose visceral (e de tantas outras enfermidades) não é uma condição excepcional, sendo apenas uma questão de tempo para que a doença se expanda para outras cidades, outros Estados, seguindo a trilha do crescimento desordenado, da pobreza, da desesperança, dos homens migrantes e de seus companheiros fiéis, os cães.

A primeira notícia, do ano de 1993, a comentar a existência de calazar canino em Belo Horizonte, trata deste tema de forma indireta. Observa-se
${ }^{7}$ Segundo Deane (1956), o cão é, sem dúvida, o principal reservatório não humano da leishmaniose visceral. Isto se justifica pelo

fato de o cão

desenvolver um intenso parasitismo dérmico e esse persistir mesmo após o desaparecimento das leishmânias das vísceras. Sua ação enquanto reservatório se verifica, principalmente, nas proximidades de habitações humanas, uma vez que o cãoé um animal doméstico. Além disso, o animal infectado pode permanecer por longos períodos sem manifestar qualquer sintomatologia clínica, mas sendo capaz de transmitir a doença, através do vetor, para outros cães ou $o$

homem. 
que a principal referência desta matéria é o movimento grevista dos servidores públicos federais que ocorreu em 1993. A leishmaniose visceral aparece como tema secundário pelo fato de os funcionários da Fundação Nacional de Saúde (FNS), entidade responsável, nesse período, pelo controle desta doença em Belo Horizonte, também terem aderido à paralisação, o que poderia acarretar um possível prejuízo da campanha de controle. A paralisação dos funcionários públicos funciona como articulador do tema leishmaniose visceral, ou seja, é a partir do primeiro acontecimento que o segundo aparece como evento significativo.

A única matéria que trata, em específico, da leishmaniose visceral em Belo Horizonte, apresenta um conteúdo eminentemente informativo. São apresentados aspectos biológicos relacionados à doença, como seu caráter parasitário, forma de transmissão, além de explicações sobre a urbanização e as atividades de controle desenvolvidas pela SMSA/PBH. O título desta matéria alerta para a presença da doença em Belo Horizonte: "Leishmaniose visceral sai do campo e começa a chegar a BH” (Leishmaniose..., 1993)

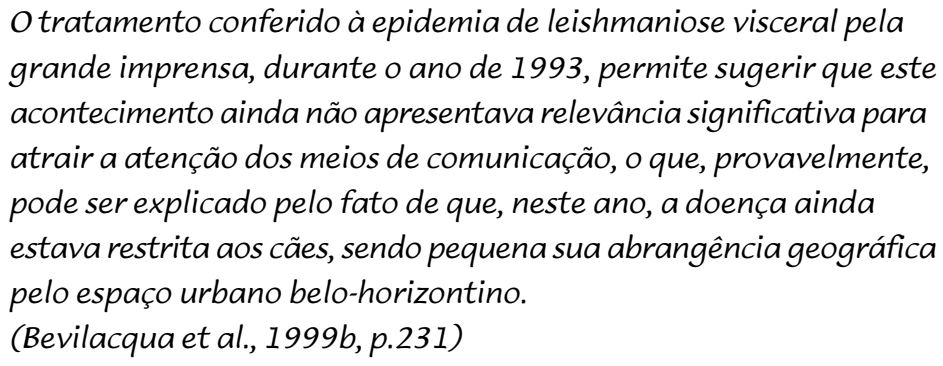

Ressaltamos que o principal eixo temático utilizado pela grande imprensa neste momento caracterizou-se pelo discurso científico. Privilegiar o discurso científico confere verossimilhança e credibilidade à matéria, como já evidenciado em estudos semelhantes que analisaram as construções narrativas e discursivas sobre a Aids (Herzlich \& Pierret, 1992; Soares, 1998). O discurso mediático utiliza a ciência, já que as concepções médicocientíficas acerca da saúde/doença exercem importante papel cultural em nossa sociedade, para fazer valer a informação por ele veiculada. Não se trata de discutir a veracidade do conhecimento divulgado, mas entender que ao mesmo tempo que a grande imprensa se apropria do discurso médicocientífico como forma de atribuir 'uma verdade' às suas matérias, o conhecimento tornado público adquire legitimidade na sociedade, conforme nos relata Camargo Júnior (1995, p.18):

...o grande eixo de sustentação da produção de sentido em nossa sociedade é a chamada 'ciência'. Ainda que sob uma crítica mais veemente agora do que há trinta ou quarenta anos, o papel hegemônico da ciência em nossa cultura segue sem grandes abalos [...] basta esta constatação: no ocidente, dizer-se que algo é científico equivale a dizê-lo verdadeiro, fundamentado, merecedor de crédito. Um papel fundamental neste processo de ordenação do mundo é desempenhado pelos meios de comunicação de massa. 


\begin{abstract}
Apresentando quase invariavelmente uma visão mágica da ciência, onde a argumentação é substituída pelo apelo à autoridade dos cientistas, a divulgação científica é uma arena importante para o estabelecimento e difusão das verdades.
\end{abstract}

\title{
"Surto de leishmaniose atinge Belo Horizonte"8
}

O interesse pela doença cresce notavelmente durante o ano de 1994, no qual foram publicadas, pela grande imprensa, 35 matérias sobre o tema "leishmaniose visceral". Destas, vinte falaram, especificamente, da epidemia da doença no município de Belo Horizonte.

No primeiro semestre de 1994, as matérias publicadas pela mídia ainda reservam o caráter informativo, versando sobre temas variados como: atividades desenvolvidas pelo serviço público para o controle da epidemia, localização espacial dos casos caninos, além de dados gerais sobre a doença, como transmissão, sintomas no homem e no cão e características sobre o vetor. Os emissores destas informações foram identificados como profissionais da SMSA/PBH e professores do Instituto de Ciências Biológicas da Universidade Federal de Minas Gerais (ICB/UFMG). Este momento também privilegia o discurso científico na elaboração das matérias jornalísticas.

No ano de 1994, a grande imprensa institui um novo discurso ao tratar da leishmaniose visceral, que denominamos "discurso do Estado", no qual são emissores os profissionais ligados à SMSA/PBH e à SES/MG. As matérias agrupadas no grupo temático Estado trazem informações sobre as atividades de controle desenvolvidas pelos órgãos públicos para combater a epidemia. As palavras/expressões utilizadas pelo discurso mediático, no início do ano, não denotam prenúncio negativo sobre a ocorrência do calazar canino em Belo Horizonte, entretanto fica clara a posição representada pelo Estado como aquele que deve ordenar e legislar em nome da saúde pública. Neste sentido, a principal imagem associada ao Estado é a de exercer "atividades de controle", é aquele que age e/ou move a ação, fazendo o agir, conforme se pode verificar nos títulos de algumas matérias transcritos abaixo:

Com o passar dos meses, há o agravamento da epidemia canina, porém ainda restrita aos Distritos Sanitários (DS) Leste e Nordeste. 
${ }^{9} \mathrm{O}$ ano de 1994 contou com 29 casos de calazar humano, sendo que quatro foram diagnosticados no primeiro semestre, nos meses de fevereiro, março e junho, e o restante durante $o$ segundo semestre do ano, conforme informações do SVCZ/ SMSA/PBH (Dados disponíveis, mas não publicados).
Qualitativamente, este fato passou a ser explorado pela grande imprensa pela mudança nas palavras/ expressões utilizadas pela mídia. Estas passam a sugerir que a leishmaniose visceral canina constitui um sério problema de saúde pública em Belo Horizonte, como percebe-se nos títulos a seguir:

"Leishmaniose é uma ameaça maior no bairro

Santa Inês" (Leishmaniose..., 1994b)

"Epidemia de doença canina atinge o Santa

Inês” (Epidemia..., 1994)

"Surto de leishmaniose atinge Belo Horizonte" (Barcelos, 1994)

"Polêmica: Fundação de Saúde teme surto de leishmaniose em BH"

(Polêmica..., 1994)

Apesar de a leishmaniose visceral já começar a se manifestar na população humana, a partir do ínicio de $1994^{\circ}$, apenas três matérias fazem referência à existência de casos humanos de calazar, durante o primeiro semestre desse ano. Além disso, são usadas expressões como "suspeita" e "apenas", o que caracteriza o desinteresse demonstrado pela grande imprensa, provavelmente, pelo fato de a epidemia humana não ter alcançado ainda magnitude significativa em termos numéricos e por nenhum caso ter evoluído para o óbito.

\footnotetext{
"Há suspeita, inclusive, de que uma criança tenha sido infectada pela doença.” (Leishmaniose..., 1994a)

"O Departamento de Zoonose vem comprovando que em Belo Horizonte a leishmaniose tem aparecido apenas no cachorro, uma vez que somente dois casos de contaminação humana foram notificados." (Saúde..., 1994)
}

Durante o segundo semestre de 1994, especificamente a partir do mês de setembro, a atenção sobre a leishmaniose visceral adquire novo incremento trágico: o óbito, por calazar, de duas crianças internas da Fundação Estadual para o Bem-Estar do Menor, a Febem. Durante o mês de outubro, duas notícias comentam este acontecimento, com a referência sendo feita, inclusive, no título, como verifica-se numa delas:

\footnotetext{
"Duas crianças morrem na Febem com leishmaniose"

"Seis casos de leishmaniose visceral foram registrados na Região Leste de Belo Horizonte, nos últimos 10 dias. Na Fundação Estadual do Bem-Estar do Menor (Febem), no bairro Horto, duas crianças abrigadas na creche da instituição já morreram vítimas da doença, antes mesmo de ser diagnosticada." (Duas..., 1994)
}

Percebe-se, no discurso mediático, mesmo quando se trata do falecimento das crianças, um conteúdo eminentemente informativo, ou seja, os óbitos das crianças internas da Febem constituem mais um item que caracteriza a 
epidemia de leishmaniose em Belo Horizonte, assim como sua definição, forma de transmissão, sintomas, reservatórios e métodos de controle. Adicionalmente, em duas matérias publicadas durante o mês de outubro de 1994, os casos de calazar ocorridos na Febem apareceram como tema secundário, articulados ao afastamento do presidente dessa instituição, apesar dos óbitos mencionados.

Este aspecto é explorado por Castro (1997), ao analisar o fenômeno Ângela Diniz na grande imprensa. Esta autora, considerando a imprensa como "um espaço conflagrado de sentidos" observa que os acontecimentos noticiados no meio jornalístico estabelecem, no

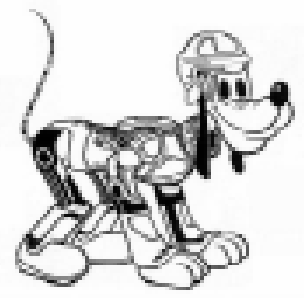
público leitor, níveis diferentes de identificação, podendo, em um extremo, haver o completo ajustamento entre acontecimento/leitor e, no outro, a completa repulsa. $A$ concordância ou não com a idéia publicada seria, então, dependente dessas identificações.

No caso dos óbitos ocorridos entre as crianças internas da

Febem, torna-se óbvio que estas não encontram, em nossa sociedade, uma matriz de sentido de identificação positiva, ou seja, são crianças sem família, sem referência, sem nome que estão sendo vítimas da leishmaniose visceral, o que torna o acontecimento irrelevante.

\section{"Leishmaniose visceral: epidemia já se alastrou à Zona Sul”Io}

Quantitativamente, o ano de 1995 foi similar ao ano anterior, tendo sido publicadas, pela grande imprensa, 38 matérias jornalísticas abordando o tema leishmaniose visceral. Deste total, 28 notícias tratam da epidemia de leishmaniose no município de Belo Horizonte, em especial.

A análise da evolução espacial da epidemia de leishmaniose visceral na

10 Leishmaniose... (1995d) cidade revelou a expansão da doença para outros distritos, além dos DS Leste e Nordeste, já durante o ano de 1994, fato este agravado durante os anos subseqüentes, 1995 e 1996 (Bevilacqua, 1999).

Entretanto, este acontecimento só é noticiado pela grande imprensa no início de 1995, referindo-se, especificamente, ao DS Centro-Sul. As duas primeiras matérias desse ano, publicadas no mês de fevereiro, trazem em seus títulos referência da presença do calazar canino naquele distrito. Posteriormente, no mês de setembro, uma outra matéria também cita, em seu título, que a leishmaniose visceral chegou à zona sul da capital mineira. A presença da doença em outros distritos não é tratada com o mesmo destaque, revelando um tratamento diferenciado, pela mídia, quando ela passa a ocorrer na "zona sul" de Belo Horizonte, região constituída por bairros com alto padrão de ocupação e que congregam grande parte da população de classe média e alta do município.

As matérias que noticiam a presença do calazar canino no DS CentroSul instituem, na construção narrativa e discursiva do calazar, um terceiro discurso, o discurso social, representado pelas falas e opiniões de moradores de bairros atingidos localizados no distrito. A mídia ainda não havia utilizado os discursos de indivíduos residentes em bairros dos DS Leste e Nordeste ou mesmo de outros bairros posteriormente acometidos 
${ }^{11}$ Texto transcrito da matéria:

Leishmaniose...

(1995b)

${ }^{12}$ Texto transcrito da matéria: Zona... (1995)

${ }^{13} \mathrm{O}$ teste utilizado pela prefeitura era a imunofluorescência indireta, o qual apresenta sensibilidade de $98 \%$ e especificidade de $70 \%$ sendo, inclusive, recomendado pelo Ministério da Saúde para todo o país. Esta recomendação é norteada por vários critérios, pois, numa situação epidêmica, em que se tem como objetivo o controle de um determinado agravo, a eleição do teste a ser usado como meio diagnóstico deve atender a alguns requisitos, como: baixo custo, simplicidade, reprodutibilidade, alta sensibilidade (poucas reações falso-negativas) e alta especificidade (poucas reações falsopositivas).

${ }^{14} \mathrm{~A}$ detecção concomitante da leishmaniose visceral e de outras enfermidades, como a leishmaniose

tegumentar e a doença de Chagas, pelo teste de imunofluorescência indireta, não invalida sua eleição como teste diagnóstico, pois, também para as outras doenças mencionadas, a recomendação é de sacrifício do animal positivo, já que não existe tratamento eficaz para o animal doente em nenhuma das enfermidades citadas. pelo calazar.

Percebe-se que a relevância conferida pela grande imprensa para a população residente no DS Centro-Sul é diferente daquela destinada à população de outros distritos, estando a primeira, inclusive, autorizada a se pronunciar no espaço jornalístico.

As matérias jornalísticas que comentam o aparecimento da leishmaniose visceral no DS Centro-Sul permitem identificar a representação social que a população desta área tem a respeito dessa doença. Para os moradores desses bairros o calazar seria "coisa de cachorro de gente pobre, sem higiene $e$ sem alimentação adequada" 1 , ou que a "doença fosse um problema restrito às favelas e que só atingisse animais desnutridos e raquiticos ${ }^{\prime 12}$, o que explica a admiração que as pessoas manifestam quando a doença passa a acometer os cães pertencentes a proprietários residentes no distrito.

Neste período foram identificadas algumas matérias que questionam a validade dos exames realizados pela $S M S A / P H^{13}$, ou seja, de que estariam identificando grande número de animais falso-positivos e de que não seriam os mais específicos para o diagnóstico da leishmaniose visceral, pois poderiam apresentar reação cruzada com outras enfermidades como a leishmaniose tegumentar ou a Doença de Chagas ${ }^{14}$.

Entretanto, refletindo sobre o tipo de teste ainda utilizado para o diagnóstico desta zoonose, descrita pela primeira vez no Brasil por Penna em 1934 (Rodrigues da Silva, 1957; Pessôa E Martins, 1982), observa-se que muito tímida foi a evolução do conhecimento científico nessa área, quando comparamos a enfermidade com a Aids. Há aproximadamente cincoenta anos utiliza-se praticamente a mesma técnica diagnóstica para a identificação do calazar, sendo inclusive conhecidos os problemas relacionados aos falso-positivos, enquanto o fenômeno Aids suscitou uma revolução em tecnologia no que diz respeito ao diagnóstico, tratamento e controle desta enfermidade, em poucos vinte anos.

Neste sentido, Soares (1998, p.68), a partir da idéia de Derrida de que o espaço da experiência técnica entre o saber e a habilidade tende a se tornar cada vez mais animista, mágico e mítico, comenta que:

\footnotetext{
A contemporaneidade, portanto, reveste-se de elementos cada vez mais míticos pela desproporção que se estabelece entre o que se conhece e o que se sabe. Em linhas gerais, trata-se de um profundo desconhecimento em relação às novas tecnologias e aos objetos usados no cotidiano, funcionando da mesma forma que o fanatismo religioso ao criar o obscurantismo, o mítico, o mistério, o desconhecido. A Aids enquanto doença parece ser já bastante conhecida (a questão da informação), mas dela pouco se sabe (e é essa a busca incessante da ciência).
}

Ainda neste paralelo com a Aids, da leishmaniose visceral pouco se conhece e pouco se sabe. Esta diferença revela a existência de critérios não imparciais e, por isso, nem sempre comprometidos com determinadas parcelas da sociedade, orientando a produção do conhecimento científico, pois à medida que o calazar se mantém restrito ao ambiente rural, ceifando as vidas dos 


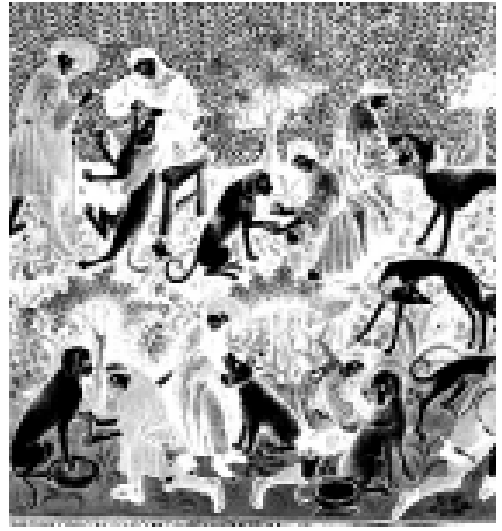

trabalhadores do campo ou de crianças subnutridas, não se esperam investimentos para o controle ou erradicação desta doença.

A partir do discurso proferido pelos moradores da Zona Sul, também podemos perceber que as reivindicações desses moradores merecem espaço na grande imprensa, o que não se verificou quando a doença estava restrita a outros distritos. Na verdade, estas reivindicações traduzem anseios da população de Belo Horizonte de uma forma geral, pois exigem um maior esclarecimento, por parte da prefeitura, com relação à epidemia de calazar.

Assim como esta proprietária, outras da vizinhança da rua Henrique Sales estão entendendo que a situação é de alerta. 'Depois da morte de meu cachorro, saí de vizinho em vizinho avisando dos riscos', conta Leda Valadares. Ela quer saber de mais detalhes sobre a doença, como seu cão foi contaminado e como a doença se prolifera. 'Faço a minha parte cuidando pessoalmente da higiene do canil, mas não sei se isso é tudo que devo fazer'.

Luiza Ramos diz que a presença dos técnicos do Serviço de Zoonoses deve ser bem-vinda a todos os proprietários. Primeiro, porque é gratuita e esclarecedora. Depois, serve de alerta a todos. 'Se o pessoal não tivesse aparecido por aqui, não saberíamos desta situação. Estamos todos apreensivos, mas o fato existe e deve ser encarado'.

O que os moradores reclamam é mais esclarecimento por parte dos técnicos do Serviço de Zoonoses. Eles querem mais informações sobre a doença, saber se há outros casos notificados e, principalmente, o resultado dos exames de sangue.

(Leishmaniose..., 1995b)

Na transcrição acima podemos perceber que, para esses moradores, $o$ Serviço Público exerce, eminentemente, uma função informativa, não sendo reconhecido seu papel de promotor da saúde. Esta concepção apresenta conseqüências importantes, pois uma vez que as ações planejadas pela prefeitura não têm legitimidade neste espaço, sua execução pode sofrer impedimentos, determinando, inclusive, sua inviabilidade. Essas dificuldades foram, de fato, vivenciadas pela SMSA/PBH, pois quando as atividades de coleta de sangue dos cães e o sacrifício dos animais positivos foram estendidas para os bairros do DS Centro-Sul, houve resistência por parte dos moradores em aceitá-las e colaborar com as recomendações do serviço público, conforme constata-se no texto abaixo:

Segundo denúncias da proprietária de um cão, Divina Duarte, também moradora do Luxemburgo, quando os técnicos chegavam, as pessoas alegavam que tinham veterinários particulares e que não iam deixar seus cães serem examinados. 'Havia até um certo 
constrangimento deles ao se aproximar de nossas casas. Era como se estivessem pedindo desculpas pelo incômodo. (Leishmaniose..., 1995b)

Concomitantemente, o discurso da mídia revela-se como de natureza não neutra, pois uma característica importante das matérias jornalísticas publicadas durante o ano de 1995 é o fato de a leishmaniose visceral ser tratada, pela grande imprensa, como uma ameaça à população, e sua expansão, pelo espaço urbano belo horizontino, como decorrente de atitude negligente por parte do serviço público, conforme os títulos de algumas notícias:

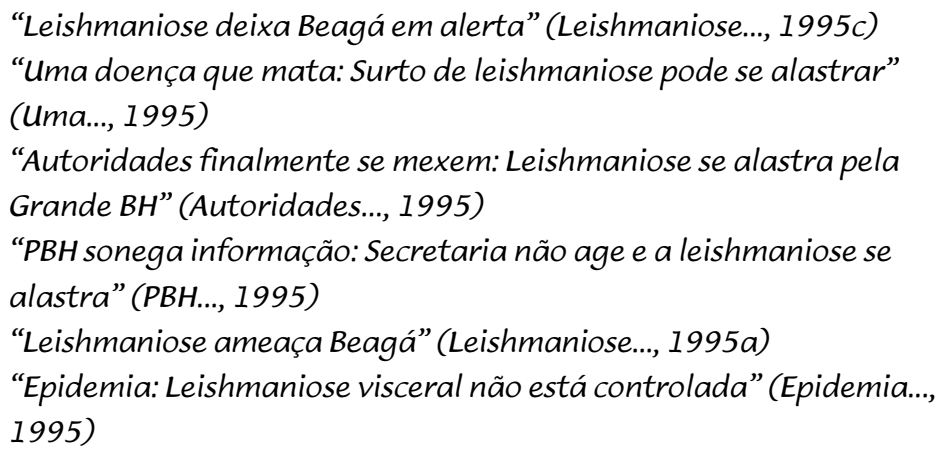

As matérias que apresentaram um discurso temático relacionado ao Estado apresentaram informações contraditórias, ora revelando que a situação ainda se comportaria de forma epidêmica, ora informando que a doença estaria controlada. Neste momento, a SMSA/PBH utiliza informações estatísticas para comprovar que a situação epidêmica estaria controlada, pois a existência de poucos casos em 1995, quando comparado com o ano de 1994, mostraria uma tendência decrescente dos casos humanos em Belo Horizonte. A utilização da informação estatística associada a palavras como "apenas" e "somente" torna trivial a ocorrência de poucos casos de calazar humano, sendo semelhante o efeito quando a referência é feita aos óbitos:

Em 1994 foram registrados 17 casos na região Leste, 12 na Nordeste, incluindo seis óbitos. Este ano, a região Nordeste apresentou apenas um óbito, incluído em 11 casos. Nos distritos Norte e Oeste foram um e seis no Leste. Sendo que nos meses de junho e julho não foram registrados (sic) nenhum caso', afirmou a epidemiologista Gilvânia Cosenza, do Núcleo de Epidemiologia. (Contratação..., 1995)

Sem dúvida que o tratamento quantitativo da epidemia de calazar é de utilidade para a caracterização e o acompanhamento deste processo na população, entretanto, não é aconselhável que se desconsidere ou se trate com menor importância a ocorrência do evento quando este não possuir a devida "significância estatística".

Neste sentido, apesar de os dados quantitativos indicarem uma tendência 
decrescente da epidemia de calazar, não foi esta a situação vivenciada por Belo Horizonte. O ano de 1995 chega ao seu fim com a notificação de 45 casos humanos de leishmaniose visceral e o total de quatro óbitos, além do comprovado aumento e expansão da epidemia canina no município (Bevilacqua et al., 1999b).

\section{6: A personalização do animal doméstico}

O ano de 1996 contou com 22 matérias jornalísticas publicadas na grande imprensa sobre o tema leishmaniose visceral, sendo que onze referiam-se, especificamente, à epidemia em Belo Horizonte. Percebe-se que houve um razoável declínio quantitativo das notícias, quando comparado com os anos de 1994 e 1995.

O caráter informativo das matérias é também perpetuado ao longo desse ano. Entretanto, uma característica interessante, identificada em três matérias jornalísticas, aparece: a utilização do recurso jornalístico da personalização, pelo discurso mediático. Duas matérias trabalham a personalização do animal e a terceira apresenta a história de uma criança acometida pelo calazar. A personalização do animal também havia sido identificada no ano de 1995 em uma matéria publicada no mês de fevereiro.

O processo de personalização, segundo Wolton apud Castro (1997), é um recurso utilizado pelos meios de comunicação que possibilitaria, a partir da emergência dos acontecimentos, a atuação da mídia sobre a realidade. Uma dessas formas de atuação seria no sentido de que:

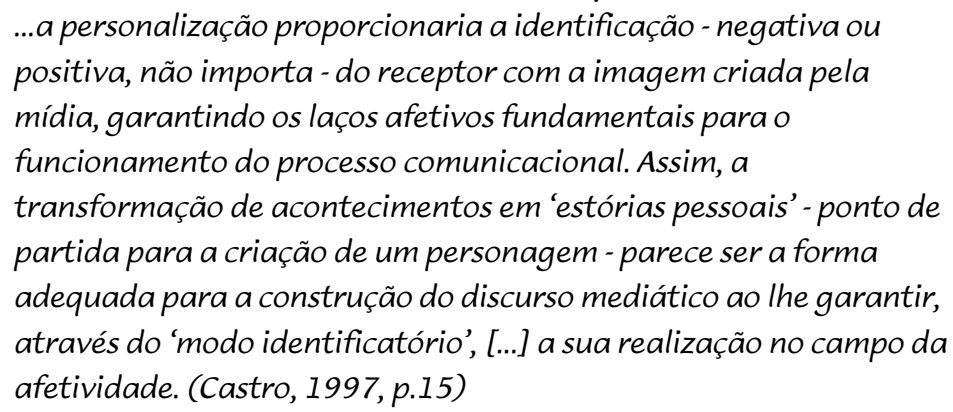

Mediante este recurso a grande imprensa relata histórias de interesse humano, permitindo a identificação do leitor com a história relatada. $A$ intenção de capturar a atenção do leitor tem uma finalidade econômica, pois estimulando a aquisição do jornal, este é vendido.

Ainda considerando o processo de personalização realizado pela mídia, Castro (1997) acrescenta que este só poderá se efetivar com o consentimento do sujeito que fornece a base para sua concretização, ou seja, é preciso que o indivíduo "consinta na sua conversão em personagem e que assuma um comportamento performático garantindo os efeitos mediáticos” (p.16).

No caso específico da leishmaniose visceral, o processo de personalização do animal não se dá, obviamente, com o consentimento deste, mas, indiretamente, por meio de seus donos: 
${ }^{15}$ Esta matéria foi publicada quando a leishmaniose visceral passou a ser identificada no DS Centro-Sul. A transcrição refere-se ao depoimento de uma moradora do bairro Luxemburgo, pertencente a este distrito.
Jamila Duarte Mourão, proprietária do pequeno Luppi, tomou as precauções indicadas pelos veterinários do Serviço de Zoonoses e outras pessoas para evitar qualquer tipo de risco. Os veterinários recomendaram evitar levar o cão à rua, entre cinco e seis horas da tarde, oportunidade em que os mosquitos ficam mais ativos e costumam picar mais. 'Nunca mais levei Luppi neste horário para passear'.

As medidas adotadas por Jamila Duarte e que devem ser seguidas são as seguintes: se o cão tiver orelhas grandes, 'eu prendo com uma borrachinha para evitar que elas toquem o chão'. E o cão só sai à rua para suas necessidades fisiológicas com uma camiseta que cobre todo o dorso do animal. 'Assim evito que os mosquitos o piquem'. (Leishmaniose..., 1995b) ${ }^{15}$

O cão de estimação da família de Ângela, um poodle toy, carinhosamente apelidado de 'Floquinho', terá de ser sacrificado e ninguém da casa conforma-se com a morte do animal. A costureira disse que comprou o

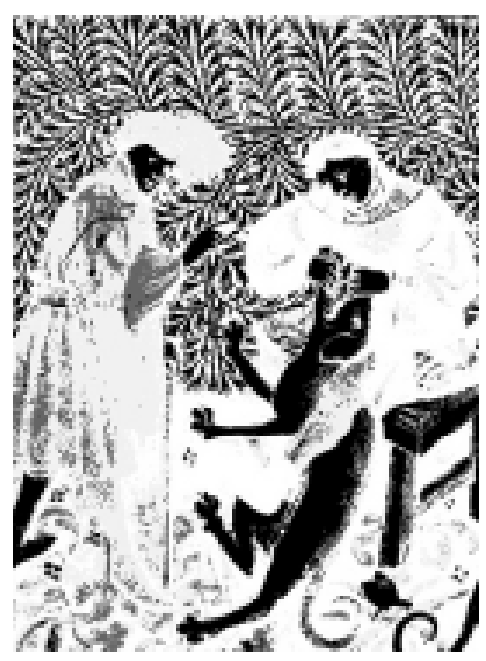
cão em 1990, por 3 salários mínimos, para presentear a filha Luana de Jesus Belisário, de 8 anos, que havia perdido o pai em consequência de um acidente automobilístico. 'Foi uma tentativa de amenizar o trauma causado pela morte do meu marido, uma recomendação da psicóloga. Hoje Floquinho é o xodó da família', contou a costureira. (Costureira..., 1996)

Segundo Castro (1997), o modo característico de funcionamento do personagem criado pela mídia se faz pelo mecanismo de sedução, ou seja, o personagem é um sedutor que busca fascinar o outro com sua imagem. Este mecanismo se daria na medida que
a sedução se dirige para aquele que do outro lado da cena - o receptor - se deixa fascinar pela teatralidade, um dos modos operatórios privilegiados pela mídia na composição da estória do personagem focalizado. É nessa dimensão de teatralidade que a estória mediática 'fisga' o receptor, produzindo a sedução que o enlaça (p.16).

A mídia, então, na encenação da estória de seu personagem com o objetivo de seduzir o receptor, cria um espaço no qual o social se apresenta de forma teatral, tornando públicas as figurações da realidade social mobilizadas nessa encenação. Dessa forma, o receptor, aqui convertido em assistência, vivencia imaginariamente as figurações do social mobilizadas nas ações do personagem mediático. A teatralização do social, enquanto modo operatório do personagem mediático, exerce seu poder de sedução de uma forma não violenta e não autoritária, pois a encenação do social é uma forma de dissimulação que tem por objetivo subtrair à atenção elementos que 
poderiam produzir repulsa ou recusa e construir algo que seja atrativo para mover o objeto da sedução na direção pretendida pelo sedutor (Castro, 1997).

No nosso tema específico, a sedução se dá pela identificação que existe entre o receptor e a estória dos cães sacrificados e seus donos sofrendo por esta perda. A imagem que se constrói e a encenação da estória do personagem se fazem utilizando-se do recurso trágico adotado na narrativa das notícias publicadas.

A maneira como a mídia constrói o discurso sobre/do personagem, ou seja, o estilo narrativo, é exatamente um outro fator necessário para que a relação entre personagem-receptor, que se conforma a partir da identificação e se consolida pela sedução, se complete (Castro, 1997).

Nas próprias palavras de Castro, "o trágico seria aquele tipo de acontecimento - artístico, ficcional, mítico, real - que, sendo capaz de suscitar compaixão e temor, promova a catarse das paixóes semelhantes a essas" (p.17). Fazendo a analogia do acontecimento trágico no âmbito da mídia com a tragédia enquanto produção artística, notadamente a tragédia grega, a autora nos aponta requisitos para o aparecimento do efeito do trágico. Um destes requisitos, que nos parece particularmente interessante e vinculado ao tema em questão, diz respeito ao fato de que o acontecimento, para obter o efeito do trágico deve ter, em alguma medida, uma

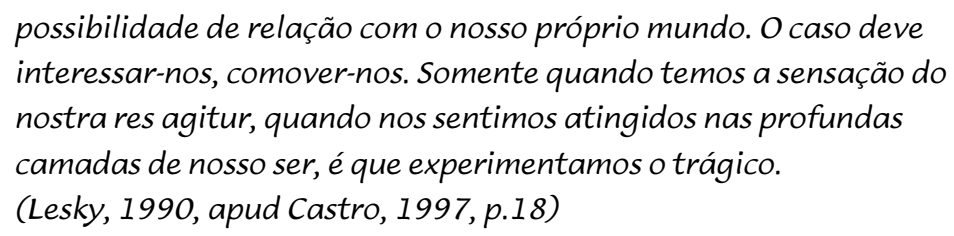

Adicionalmente, o animal que é personalizado, merecendo atenção no espaço jornalístico, é o cão de raça e pertencente a proprietários com um determinado nível sócio-econômico. São animais que aparecem nomeados e com referência, inclusive, ao seu valor econômico.

Interessante que o processo de personalização é utilizado para apresentar estórias de animais. Apenas uma matéria, no ano de 1996, comenta o processo vivenciado por uma criança acometida por calazar. Contudo, o acontecimento referente aos óbitos de crianças internas na Febem, no ano de 1994, não mereceu a mesma atenção da mídia. Para exemplificar esta diferença, as crianças que faleceram não foram sequer nomeadas no discurso mediático. O tratamento diferenciado

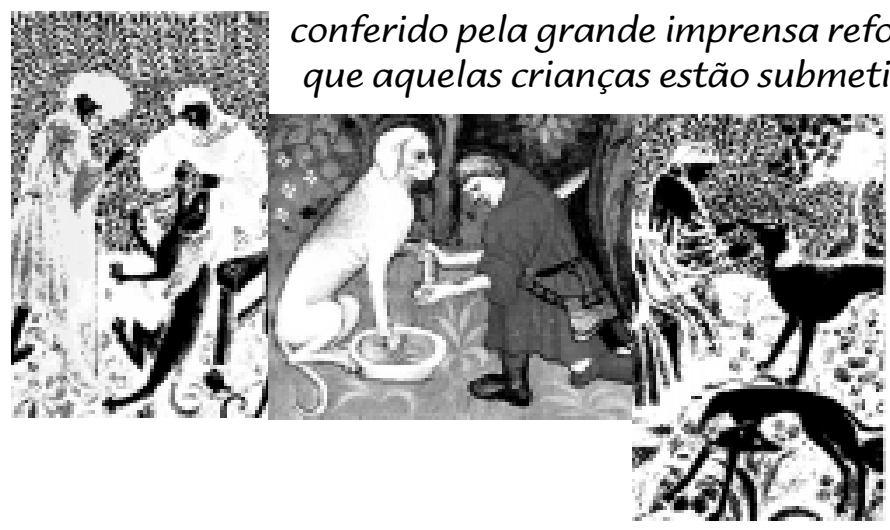

\author{
marginalizados desde o \\ discurso mediático, não \\ havendo menção à forma mais \\ simples de referência ao \\ cidadão, que é o seu nome. \\ Considerações
}


A análise desenvolvida neste trabalho reforça a idéia de que saúde/doença devam ser concebidas como processo e, sendo assim, possam encontrar vários espaços, naturalizados ou socializados, de desenvolvimento. Paralelamente à expansão geográfica e quantitativa das epidemias de leishmaniose visceral humana e canina em Belo Horizonte, conformou-se outra trajetória deste mesmo evento que extrapola os limites biológicos de ocorrências das enfermidades, qual seja, o corpo humano e animal.

Esta trajetória encontra no espaço jornalístico uma dimensão diferente de ocorrência, expressa pelo discurso mediático. Este, como expressão direta de diversos atores sociais, apresenta características próprias dos grupos sociais que representam seus emissores.

Esta gama de discursos que inunda o cotidiano das pessoas, que transforma e "enriquece" o próprio discurso do senso comum, também é capaz de produzir transformações ou reforçar atitudes e comportamentos individuais, os quais, por sua vez, se transferem para o nível coletivo, tanto pela amplificação resultante da divulgação advinda dos meios de comunicação como pelas trocas interpessoais de experiências vividas diariamente.

A doença, considerada objeto de construção social ou de representações sociais coletivas, partilhadas e comungadas por indivíduos da coletividade, encontra, no processo de comunicação, um espaço onde pode ser legitimada, por exemplo, por meio de um discurso bio-médico competente, $e$ reproduzida. Conseqüentemente, possibilita a produção de efeitos de sentido, formando e conformando conhecimentos e comportamentos variados sobre a doença, em momentos históricos particulares.

A produção e reprodução de sentidos nos indivíduos pelos meios de comunicação pode apresentar considerável relevância quando trata do tema saúde/doença, uma vez que este processo interfere na construção de comportamentos e de imaginários sociais.

Em se tratando do processo saúde-doença, os indivíduos são, em primeira e última instância, seus sujeitos e objetos; sujeitos, pois são responsáveis em transformá-lo e dinamizá-lo enquanto "processo", e objetos, pois é neles que as transformações se verificam. Os indivíduos, então, encontram nos meios de comunicação, no discurso mediático e nas opiniões proferidas, um amplo espectro de influência em seus comportamentos e atitudes, que podem obviamente determinar aspectos importantes da orientação adquirida por um evento mórbido específico.

Nesse contexto, a epidemiologia encontra sua interdisciplinariedade com a área da comunicação social, na medida que a opinião, veiculada no discurso mediático, pode produzir e reproduzir representações diversas sobre saúdel doença e se constituir em um determinante importante deste processo. 
BEVILACQUA, P.D. Leishmaniose visceral: interesses públicos e interesses privados na construção social de uma epidemia em Belo Horizonte. Belo Horizonte, 1999. 343p. Tese (Doutorado em Ciência Animal). Escola de Veterinária, Universidade Federal de Minas Gerais.

BEVILACQUA, P.D. et al. A imprensa na construção social de processos epidêmicos: o caso da leishmaniose visceral em Belo Horizonte. In: CONGRESSO DE CIÊNCIAS HUMANAS, LETRAS E ARTES, 4, 1999, Viçosa. Anais... Viçosa: Universidade Federal de Viçosa, 1999a.

BEVILACQUA, P.D., PAIXÃO, H.L., MODENA, C.M., CASTRO, M.C.P.S. Urbanização da leishmaniose visceral em belo horizonte: velhas mazelas conquistando novos espaços. Arq. Bras. Med. Vet. e Zootec., 1999b, v

CAMARGO JÚNIOR, K.R Medicina, medicilização e produção simbólica. In: PITTA, A.M.R. (Org.). Saúde \& comunicação: visibilidades e silêncios. São Paulo/Rio de Janeiro: HUCITEC/ABRASCO, 1995. p.13-24.

CARVALHEIRO, J.R. Processo migratório e disseminação de doenças. In: Textos de apoio -

Ciências Sociais. 2.ed. Rio de Janeiro: ABRASCO, 1986. n.1. p.29-55.

CASTRO, M.C.P.S. Na tessitura da cena, a vida: comunicação, sociabilidade e política. Belo Horizonte: Ed. UFMG, 1997.

CONTROLE, diagnóstico e tratamento da leishmaniose visceral (calazar). 2.ed. Brasília: Fundação Nacional de Saúde, 1996. 86p. (Normas técnicas).

DEANE, L.M. Leishmaniose visceral no Brasil, estudos sobre reservatórios e transmissores realizados no Estado do Ceará. Rio de Janeiro: Serviço Nacional de Educação Sanitária, 1956.

DERRIDA, J. La Religione. Bari: Annuario Filosofico Europeu, Biblioteca di Cultura Moderna Laterza, 1995 apud SOARES, R. de L. Aids e imprensa: escritos do jornal Folha de S. Paulo. Interface - Comunic., Saúde, Educ., v.2, n.2, p.47-74, 1998.

FOUCAULT, M. A arqueologia do saber. Lisboa: Vozes, 1972.

GENARO, O. Leishmaniose visceral. In: NEVES, D.P. Parasitologia humana. 7.ed. Rio de Janeiro: Livraria Atheneu, 1997. cap.9, p.55-72.

HERZLICH, C., PIERRET, J. Uma doença no espaço público: a Aids em seis jornais franceses. Physis, v.2, n.1, p.7-35, 1992

LESKY, A. A tragédia grega. São Paulo: Perspectiva, 1990 apud CASTRO, M.C.P.S. Na tessitura da cena, a vida: comunicação, sociabilidade e política. Belo Horizonte: UFMG, 1997. 308p.

OLIVEIRA, V.C. Os mídias e a mitificação das tecnologias em saúde. In: PITTA, A.M.R. (Org.). Saúde \& comunicação: visibilidades e silêncios. São Paulo/Rio de Janeiro: HUCITEC/ABRASCO, 1995. p.25-37.

PESSÔA, S.B., MARTINS, A.V. Parasitologia médica. 11.ed. Rio de Janeiro: Guanabara Koogan, 1982.

RODRIGUES DA SILVA, J. Leishmaniose visceral (calazar). Rio de Janeiro: Serviço Nacional de Educação Sanitária, 1957.

RONDELLI, E. Mídia e saúde: os discursos se entrelaçam. In: PITTA, A.M.R. (Org.). Saúde \& comunicação: visibilidades e silêncios. São Paulo/Rio de Janeiro: HUCITEC/ABRASCO, 1995. p.38-47.

SABROZA, P.C., KAWA, H., CAMPOS, W.S.Q. Doenças transmissíveis: ainda um desafio. In: MINAYO,

M.C.S. (Org.). Os muitos brasis: saúde e população na década de 80. São Paulo/Rio de Janeiro: HUCITEC/ABRASCO, 1995. p.177-244.

SOARES, R. de L. Aids e imprensa: escritos do jornal Folha de S. Paulo. Interface - Comunic., Saúde, Educ., v.2, n.2, p.47-74, 1998. 
Textos retirados de jornais:

AUTORIDADES finalmente se mexem: leishmaniose se alastra pela Grande BH. Estado de Minas, Belo Horizonte, 30 mar. 1995. Cidades, p.21.

BARCELOS, H. Surto de leishmaniose atinge Belo Horizonte. Estado de Minas, Belo Horizonte, 17 jul. 1994. Cidades, p.23.

BIOTÉRIO da UFMG vai desenvolver vacina contra leishmaniose visceral. Estado de Minas, Belo Horizonte, 15 jul. 1993. Cidades, p.21.

CONTRATAÇÃO de servidor: combate à leishmaniose visceral vai ser intensificado. Hoje em Dia, Belo Horizonte, 25 jul. 1995. Minas, p.19.

CONTROLE da leishmaniose: Regional Leste sacrifica 44 cães no Santa Inês. Hoje em Dia, Belo Horizonte, 01 fev. 1994. Minas, p.15.

COSTUREIRA critica o combate à leishmaniose: abraçada ao seu cão condena matança e diz que a $\mathrm{PBH}$ tem que eliminar o mosquito transmissor. Hoje em Dia, Belo Horizonte, 24 set. 1996. Minas, p.2.

DUAS crianças morrem na FEBEM com leishmaniose. Hoje em Dia, Belo Horizonte, 11 out. 1994. Minas, p.19.

EPIDEMIA de doença canina atinge o Santa Inês. Estado de Minas Belo Horizonte, 01 jul. 1994. Cidades, p.17.

EPIDEMIA: leishmaniose visceral não está controlada. Diário da Tarde, Belo Horizonte, 12 set. 1995. Cidade, p.12.

LEISHMANIOSE visceral sai do campo e começa a chegar a BH. Estado de Minas, Belo Horizonte, 02 out. 1993. Cidades, p.19.

LEISHMANIOSE ainda preocupa prefeitura. Estado de Minas, Belo Horizonte, 26 fev. 1994a. Cidades, p.21.

LEISHMANIOSE é uma ameaça maior no bairro Santa Inês. Estado de Minas, Belo Horizonte, 30 jun. 1994b. Cidades, p.20.

LEISHMANIOSE: Prefeitura inicia pesquisa sobre a doença. Diário da Tarde, Belo Horizonte, 31 jan. 1994c. Cidade, p.13.

LEISHMANIOSE: Zoonose começa pesquisa para controlar a doença. Hoje em Dia, Belo Horizonte, 09 mar. 1994d. Minas, p.15.

LEISHMANIOSE ameaça Beagá. Jornal de Casa, Belo Horizonte, 9 a 15 abr. 1995a.

LEISHMANIOSE canina: demora de exames preocupa os moradores da zona sul. Diário da Tarde, Belo Horizonte, 24 fev. 1995b. Cidade, p.11.

LEISHMANIOSE deixa BH em alerta. Hoje em Dia, Belo Horizonte, 02 mar. 1995c. Minas, p.19.

LEISHMANIOSE visceral: epidemia já se alastrou à zona sul. Diário da Tarde, Belo Horizonte, 13 set. 1995d. Cidade, p.12.

PBH sonega informação: Secretaria não age e leishmaniose se alastra. Estado de Minas, Belo Horizonte, 01 abr. 1995. Cidades, p.19.

POLÊMICA: Fundação de Saúde teme surto de leishmaniose em BH. Hoje em Dia, Belo Horizonte, 27 jul. 1994. Minas, p.19.

SANTOS, M. Desmate deflagra a "revo1 ução dos bichos". Estado de Minas, Belo Horizonte, 29 jun. 1993. Agropecuário, p.5.

SAÚDE: Zoonoses detecta leishmaniose em 200 cães de BH. Hoje em Dia, Belo Horizonte, 18 mai. 1994. Minas, p.15.

UMA doença que mata: surto de leishmaniose pode se alastrar. Estado de Minas, Belo Horizonte, 21 mar. 1995. Cidades, p.19.

ZONA Sul: leishmaniose canina se espalha em BH. Diário da Tarde, Belo Horizonte, 17 fev. 1995. Cidade, p.11. 
TABELA 1

Número de matérias publicadas e utilizadas na análise, segundo jornal e ano de publicação. Belo Horizonte, 1993 a 1996.

\begin{tabular}{|l|c|c|c|c|}
\hline \multicolumn{1}{|c|}{ JORNAIS } & \multicolumn{4}{|c|}{ ANOS } \\
\hline & 1993 & 1994 & 1995 & 1996 \\
\cline { 2 - 5 } Estado de Minas & 3 & 4 & 3 & 0 \\
\hline Hoje em Dia & 0 & 5 & 2 & 1 \\
\hline Diário da Tarde & 0 & 1 & 4 & 0 \\
\hline Jornal de Casa & 0 & 0 & 1 & 0 \\
\hline TOTAL & 3 & 10 & 10 & 1 \\
\hline
\end{tabular}

BEVILACQUA, P.D. et al. Leishmaniosis visceral: historia periodística de una epidemia en Belo Horizonte, Brasil, Interface _ Comunicação, Saúde, Educação, v.4 , n.6, p.83-102, 2000

Este trabajo trata de recuperar la historia periodística de la epidemia de leishmaniosis visceral que acomete al municipio de Belo Horizonte, Brsil, desde 1993. Tal rescate se ha hecho a través de su historia cronológica y de las construcciones narrativas y discursivas sobre la epidemia en 101 textos publicados en la prensa general durante el periodo de 1993 a 1996. Utilizándose como orientación metodológica la propuesta de Foucault (1972), en su trabajo "La Arqueología del Saber", el análisis apunta la configuración de tres grandes discursos, caracterizando grupos temáticos en las materias estudiadas: el de la Ciência, el del Estado y el de la Sociedad. Cada uno de los grupos contribuye para la construcción de la enfermedad en el espacio periodístico y divulga opiniones propias de cada uno de estos universos. De esta forma, la lectura de los textos periodísticos permite el desnudamiento de otro proceso epidémico que se desarolla paralelamente al que acomete a las poblaciones humana y canina, expresado en las construcciones narrativas sobre la leishmaniosis visceral en los textos del periódico.

PALABRAS CLAVE: leishmaniosis visceral; prensa general; epidemia.

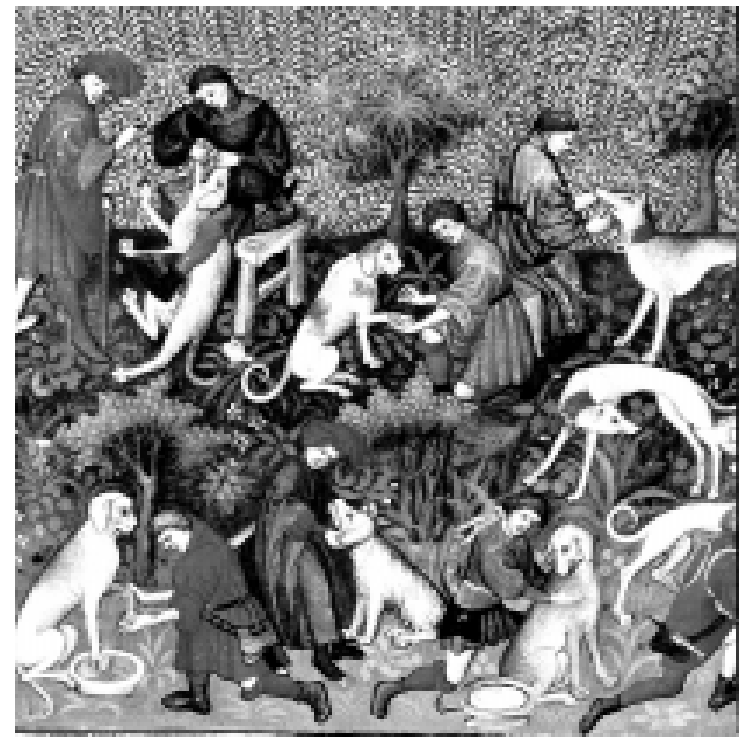

GASTON PHOEBUS, The maladies of dogs being treated. Biblioteca Nacional, Paris. 